総 説

特集 : 自己免疫性疾患の病態形成に関わる細胞・分子と臨床応用

セマフォリンと自己免疫

高松 漂 太, 熊ノ郷 淳

\title{
Involvement of semaphorins in autoimmunity
}

Hyota TAKAMATSU and Atsushi KumanOGOH

Department of Molecular Immunology, Research Institute for Microbial Diseases, Osaka University

(Received August 29, 2005)

summary

Semaphorins were identified originally as guidance cues for developing axons. However, it is becoming clear that several semaphorins are crucially involved in the immune system. For instance, Sema4D (CD100) enhances activation of B cells and dendritic cells, and Sema4A is involved in T cell priming and Th1/Th2 regulation. In addition, recent cumulative evidence reveals their importance in immunological homeostasis. We here focus on our current understanding of the roles of semaphorins in autoimmunity.

Key words_-Semaphorin; CD100/Sema4D; CD72; Sema4A; autoimmunity

抄 録

セマフォリン分子群は神経ガイダンス因子として，1990 年代の初めに同定された分子群であるが，近年神経系 以外にも器官形成や血管新生, 癌の悪性化等への関与が示唆されている. 免疫系においても Sema4D/CD 100 (以 下 CD100）が B 細胞や樹状細胞の活性化を促進することや, Sema4A が T 細胞の活性化および Th1/Th2 分化制御 に関与することが明らかとなっている. 更に, これらのセマフォリン分子の免疫ホメオスターシスへの関与も示唆 され，免疫制御におけるセマフォリン分子の重要性が認識されつつある. 本稿では, これまで明らかになつている セマフォリン分子の自己免疫への関わりに焦点を当てて紹介する.

\section{はじめに}

神経系および免疫系には多くの類似性があること が知られている，例えば，両者がホメオスターシス の維持に, ケミカルメディエーターやサイトカイン などの共通の分子を用いている点や，免疫担当細胞 である $\mathrm{T}$ 細胞と抗原提示細胞 (APC) の細胞間接 合部で，神経シナプスに類似した「免疫シナプス」 と呼ばれる高度な細胞間ネットワークを形成してい る点などが挙げられる.

セマフォリン（semaphorin ; semaphore=手旗信 号が語源）は従来発生の過程における神経成長円錐 の伸張方向を決定する神経ガイダンス因子として同 定されてきた分子群である1,2)。これまでに，八エ や線虫などの原始的な生物からヒトに至るまで約 30 種類のセマフォリン分子が同定されている. セ

大阪大学微生物病研究所分子免疫制御分野
マフォリンファミリーには分泌型と膜結合型があ り, ウイルスにコードされるセマフォリン分子も含 めてその構造的特徵から 8 つのサブクラスに分類さ れている3）（図 1). セマフォリン分子は, 細胞外領 域に約 500 アミノ酸残基からなるセマドメインと呼 ばれる領域を有する。 セマドメインは各サブクラス 間においてアミノ酸レベルで 30〜 40\%の相同性を 示し, ドメイン内のシステイン残基及び $\mathrm{N}$ 型糖鎖 付加部位はほぼ完全に保存されている. ここ数年の 筆者らを含む一連の研究により，いくつかのセマフ オリン分子やその受容体分子が, 免疫反応の調節に 重要な機能を担っていることが示されつつある4).

\section{CD100 と自己免疫疾患}

\section{CD100 の発現と活性}

CD100 は免疫系において初めて生理的に発現す ることが報告されたセマフォリンとして知られ， 1992 年フランスの Boumsell らのグループにより, 


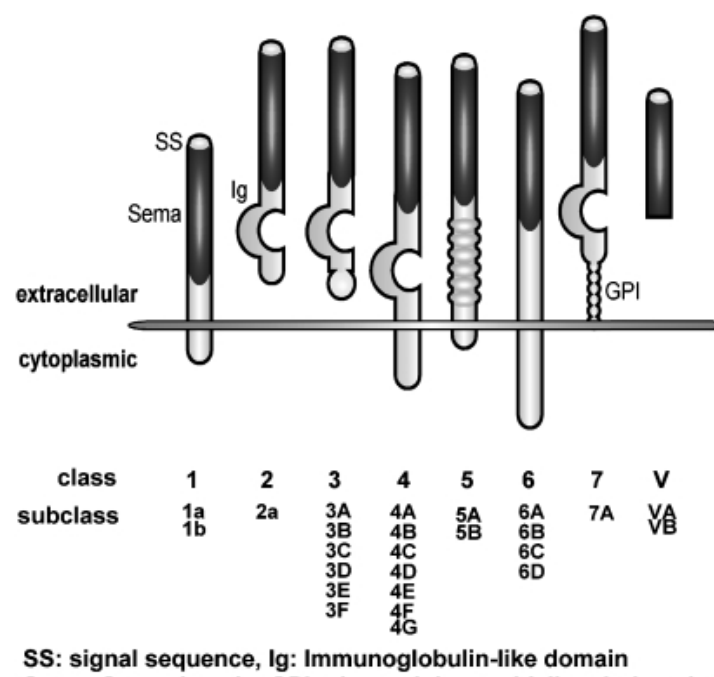

Sema: Sema domain, GPI: glycosylphospatidylinositol-anchored

図 1 セマフォリンファミリーの構造

活性化 $\mathrm{T}$ 細胞上に発現が増強し， $\mathrm{T}$ 細胞の活性化 に関与する分子として同定された5)。CD100 は細胞 外領域にセマドメインを有する膜貫通型の糖タンパ ク質で，シグナルペプチド，セマドメインに続きイ ムノグロブリンドメイン，膜貫通領域及び細胞内領 域を持ち，S-S 結合によって二量体を形成してい る.さらにリンパ球の活性化に伴って細胞表面で proteolytic に shedding を受けて分泌型 CD100 とな る6)。CD100 は T 細胞上に強く発現し，休止期の B 細胞及び樹状細胞（dendritic cell；DC）上での発現 は弱いが，CD40 刺激などによる細胞の活性化に伴 ってこれらの細胞でも発現が著しく増強する7).

可溶性リコンビナント CD100 タンパク（以下 $\mathrm{CD} 100-\mathrm{Fc}$ ) 存在下で $\mathrm{B}$ 細胞を刺激すると， CD100 単独刺激では $\mathrm{B}$ 細胞に殆ど影響を及ぼさないが, $\mathrm{CD} 40$ 抗体との共刺激により $\mathrm{B}$ 細胞の増殖及び抗体 産生が著しく克進し， $\mathrm{T}$ 細胞依存性抗原である $\mathrm{NP}-\mathrm{CGG}$ で免疫したマウスに CD100-Fc を投与す ると，抗原特異的抗体の産生六進を認めることより， CD100 の B 細胞活性化作用が示されている. 実際, CD100 欠損マウスでは in vitro における B 細胞の 増殖及び in vivo における抗原特異的抗体産生の低 下が認められている8)。逆に細胞内領域を欠失した CD100 を過剩発現する CD100 トランスジェニック マウスでは, $\mathrm{B}$ 細胞の増殖及び抗原特異的抗体産生 能が充進しており9)，これらのことから CD100が $\mathrm{T}-\mathrm{B}$ 細胞間相互作用において重要な役割を担って いることが証明されている.

\section{2. $\mathrm{CD100}$ の受容体}

1999 年イタリアの Tamagnone らにより, CD100 の受容体として Plexin-B1 が報告された ${ }^{10)}$ 。 Plexin-B1 は約 2100 のアミノ酸からなる膜タンパク質 であり, 細胞外領域にセマドメインを持ち, 他の plexin 分子とアミノ酸レベルで非常に高い相同性を 有している，神経系においては CD100 の受容体は Plexin-B1 であるが, primary のリンパ球において はその発現が殆ど認められないため, plexin-B1 と は異なる受容体の存在が示唆された，発現クローニ ングを用いた筆者らの検討により，免疫系において， CD100 は CD72 を受容体として用いていることが 明らかとなった7)。CD72 は C-type lectin ファミ リーに属する $45 \mathrm{kDa} の \mathrm{II}$ 型膜貫通型タンパク質 で, 細胞内領域に 2 つの ITIM (Immunoreceptor tyrosine-based inhibitory motifs）モチーフを有し, $\mathrm{B}$ 細胞受容体（以下 BCR）刺激によりそのチロシ ン残基がリン酸化される. リン酸化された ITIM モ チーフには, Src Homology2（SH2）ドメインを持 つチロシンホスファターゼである SHP-1 が会合し, BCR シグナルを抑制的に制御していると考えられ ている11). Parnes らによる CD72 欠損マウスを用 いた解析では，CD72 欠損マウス由来 B 細胞が種々

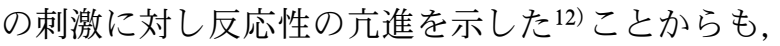
この仮説は裏付けられている，ただし，CD72が免 疫系において CD100 の唯一の受容体であるか否か については未だ不明である。最近，ヒト $\mathrm{T}$ 細胞で 活性化に伴って Plexin-B1 の発現が誘導される,さ らにPlexin-B1 発現細胞株が Sema4D を発現した chronic lymphocytic leukemia (CLL) 細胞や CD5 陽性 B 細胞の生存に関与するとの報告がなされ, Plexin-B1 のリガンドとしての作用も報告されてい

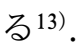

\section{CD100 欠損 B 細胞における CD72 と SHP-1 の恒常的会合}

マウス B 細胞株である WEHI231 細胞において 抗 IgM 抗体を用いて BCR を刺激すると, CD72 の チロシンのリン酸化に続いて SHP-1 の CD72への 会合が観察される。 ところがこの時, CD100-Fcで WEHI231 細胞を前処理しておくと, 抗 IgM 刺激に よるCD72 のチロシンのリン酸化および，CD72 と SHP-1 との会合は阻害される7). また, 興味深いこ とに，CD100 欠損マウスの B 細胞では，抗 IgM 刺 激前から恒常的な CD72 と SHP-1 の会合が観察さ 
れるが，CD100-Fc の前処理によって CD72 と SHP-1 の会合はほぼ完全に阻害された ${ }^{8)}$ 。これらの 結果から CD100 刺激は CD72 を脱リン酸化するこ とにより，CD72の “負の制御因子”としての機能 を解除し, その結果 B 細胞の反応性を促進するも のと考えられた.

\section{CD100 欠損下における CD72 と BCR の恒常 的会合}

それでは CD100 による CD72 の抑制性機能の解 除はどのような機構で起こるのであろうか? 野生型 $\mathrm{B}$ 細胞では BCR 刺激により CD72 と BCR 複合体 コンポーネントである CD79a（Ig $\alpha)$ との会合が認 められるが, CD100 欠損マウス由来 B 細胞では恒 常的に両者の会合が認められ，その会合は BCR 刺 激によりさらに増強した。また，野生型 $\mathrm{B}$ 細胞を BCR 刺激と共に CD100-Fc で刺激すると両者の会 合は阻害された ${ }^{14)}$ 。このことより，CD100 刺激に よりシグナル分子が集積するいわゆる BCR signalsome からCD72が sequestration され，それにより CD72 が脱リン酸化され，CD72 から SHP-1 が解 離するというモデルが示唆された（図 2). 実際,

$\mathrm{CD} 100$ 欠損 B 細胞では CD72 と BCR との会合に より, BCR 刺激による CD79b, Syk, BLNK, Fc $\gamma$ RIIB，Erk-2 のチロシンリン酸化が減弱してお り, BCR 刺激による $\mathrm{Ca}^{2+}$ mobilization も野生型に 比べ著しく減弱していた。

\section{CD100 欠損マウス由来 B 細胞のアポトーシ} 又抵抗性

CD100 による BCR シグナル強度の調節は生理的 にどのような意義を有するのであろうか? 固相化し た抗 IgM 抗体で BCR を強く架橋すると, B 細胞の アポトーシスが誘導される.しかし CD100 欠損 B 細胞は, 前述したように BCR シグナル強度が減弱 しているため, BCR 過剩刺激によるアポトーシス 誘導に対し抵抗性であった。 一方, 抗 IgM 抗体の $\mathrm{F}(\mathrm{ab})_{2}$ フラグメントで $\mathrm{BCR}$ を中等度架橋すると, CD100 欠損 B 細胞の増殖は野生型 B 細胞に比し低 下していたが， BCR と Fc $\gamma$ RIIB とを同時に架橋で きる intact な抗 IgM 抗体で刺激すると, 野生型 B 細胞は Fc $\gamma$ RIIB による negative feedback 機構によ りその増殖が抑制されたのに対し，CD100 欠損 B 細胞では増殖抑制効果が認められなかった。このこ とより CD100 欠損は B 細胞の細胞死に影響を与え

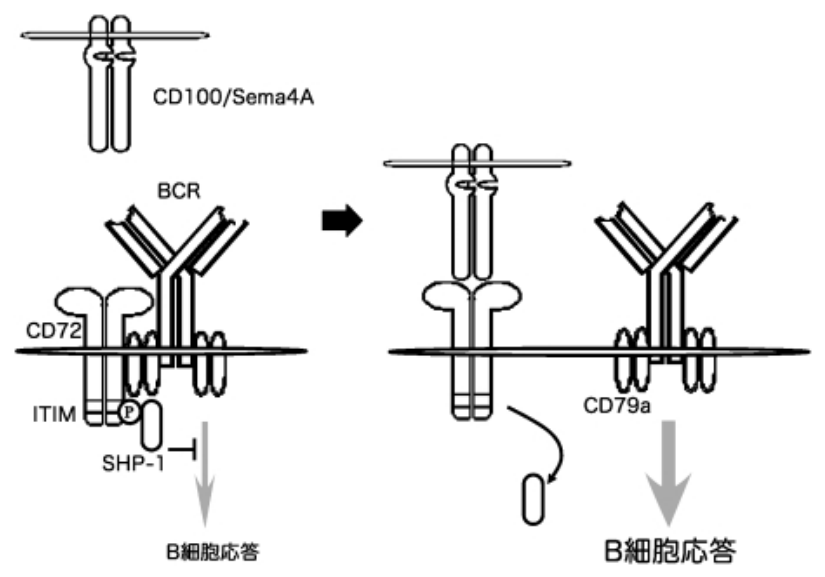

図 $2 \mathrm{~T}$ 細胞/ $\mathrm{B}$ 細胞間の CD100-CD72 のシグナル

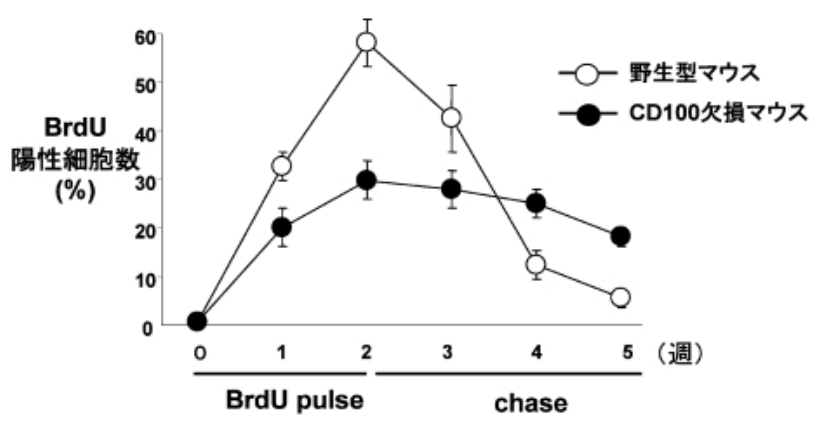

図 $3 \mathrm{CD} 100$ 欠損 B 細胞のターンオーバー障害

るのみならず，Fc $\gamma$ RIIB による negative feedback 機構にも影響していることが示唆された. CD100 欠損 B 細胞がアポトーシスに抵抗性であったこと から, 生体内での B 細胞のターンオーバーについ て検討した。野生型および CD100 欠損マウスに BrdUを含んだ水を 2 週間与え（pulse）, その後 BrdUを含まない水を与えて (chase), BrdUを取 込んだ脾臓 B 細胞の割合を経時的にフローサイト メトリーで評価した. CD100 欠損マウスは pulse 相 における BrdU の取込み陽性細胞の割合が野生型に 比し少なく, chase 相において, BrdU 取込み細胞 の消失の遅延が認められた（図 3).このことから CD100 欠損マウスでは BCR 刺激の減弱のため, in vivo における B 細胞のターンオーバーが障害され ていると考えられた。

\section{CD100 欠損マウスの加齢に伴う自己免疫疾 患発症}

$\mathrm{CD} 100$ 欠損 B 細胞での BCR シグナル減弱の影 響により, $\mathrm{B}$ 細胞の亜集団に変化が生ずるか否か脾 臓 $\mathrm{B}$ 細胞で検討した. CD100 欠損マウスでは加齢 に伴って徐々に CD2 $1^{\text {high }} \mathrm{CD} 23^{\text {low }}$ の辺縁帯 B 細胞 


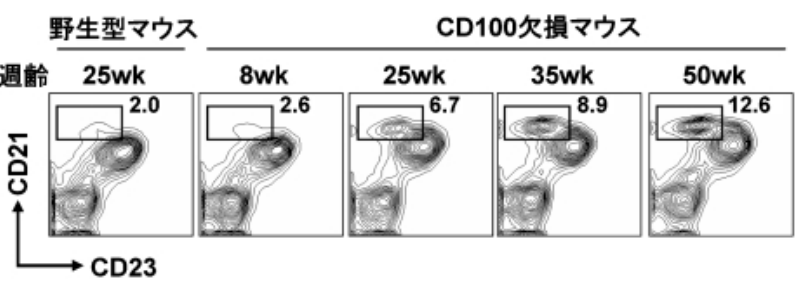

図 $4 \mathrm{CD} 100$ 欠損マウスの加齢による MZB 細胞の蓄積

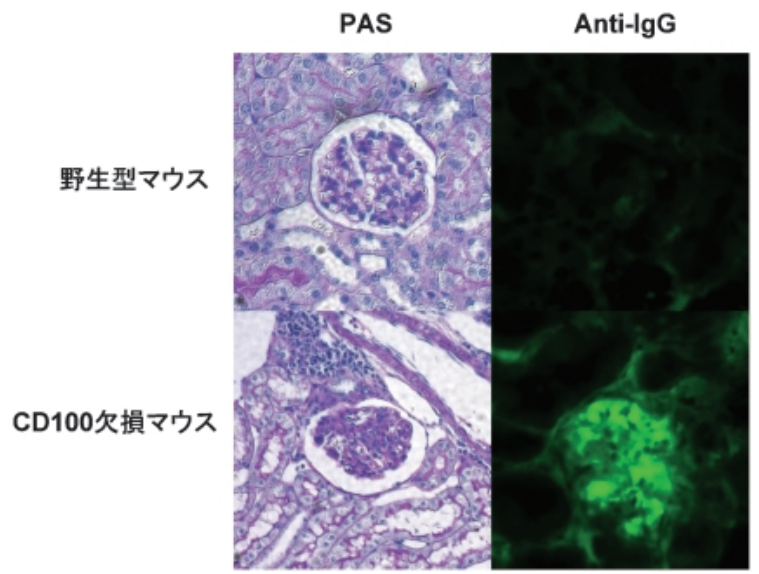

図 $5 \mathrm{CD} 100$ 欠損マウスの自己免疫性糸球体腎炎

(marginal zone B cell ; MZB) 数の増加が認められ た（図 4). 更に CD100 欠損マウスでは MZB 細胞 の増加に伴い，25 週齢を過ぎると抗 ssDNA 抗体, 抗 dsDNA 抗体, リウマチ因子, 抗 SSA 抗体, 抗 RNP 抗体などの自己抗体価の上昇を認めた。組織 学的な検討を加えると, CD100 欠損マウスでは, 唾液腺, 肝臓や，腎臟の傍血管周囲に著しい炎症細 胞の浸潤を認めた。特に糸球体はPAS 染色陽性の 基底膜の肥厚像之免疫染色にて $\mathrm{IgG}$ の沈着を認め た（図 5)。さらに，セルソーターを用いて CD100 欠損マウスの脾臓から $\mathrm{CD} 21^{\text {high }} \mathrm{CD} 23^{\text {low }}$ の MZB 細 胞と $\mathrm{CD} 21^{\text {low }} \mathrm{CD} 23^{\text {high }}$ の濾胞 $\mathrm{B}$ 細胞（follicular B cells；FB）を採取し，自己抗体産生細胞の同定を試 みると，MZB 細胞が主な自己抗体産生細胞である ことが分かった。一方，CD100 と CD72二重欠損 マウスでは MZB 細胞の増加および自己免疫疾患の 発症は認めず，CD100-CD72 相互作用の免疫ホメ オスターシス維持への関与が強く示唆された. 次に,

$\mathrm{T}$ 細胞の自己反応性六進が自己免疫疾患発症の原因 である可能性を検討したが， CD25 陽性の調節性 T 細胞（regulatory T cell ; Treg）の数およびその機能 に異常は認めず，CD69 などの $\mathrm{T}$ 細胞の活性化マー カーの発現にも有意な差は認めなかった。さらに, ヌードマウスに野生型および CD100 欠損 $\mathrm{T}$ 細胞を
移入して自己抗体価が上昇するか否かについて検討 したが，両者ともに自己抗体価の上昇は認めず $\mathrm{T}$ 細胞の自己反応性の充進の関与は否定的であった. 以上のことより, CD100 欠損マウスにおける自己 免疫疾患発症の原因は, CD100-CD72 相互作用の 欠如により生じる BCR シグナルの異常に起因する と考えられた ${ }^{14)}$.

\section{7. 分泌型 CD100 の MRL/Ipr マウスの血清中の 上昇}

前述したように CD100 は膜型のセマフォリン分 子であるが, リンパ球が活性化されると shedding を受けて可溶性分子となる。筆者らは可溶性 CD100 を検出する ELISA のシステムを確立し，種 々の免疫反応時の血清中の CD100 を測定した。 T 細胞依存的な抗原で免疫した際, 抗原特異的な抗体 価の上昇に比例して分泌型 CD100 の上昇を認め た。さらに，ヒトの自己免疫疾患である全身性エリ テマトーデス (systemic lupus erythematosus ; SLE) のモデルマウスとして知られる MRL/lpr マウスに おいて, 自己抗体価の上昇が起こる 16 週頃から自 己抗体価の上昇と一致して血清中に分泌型 CD100 の著しい上昇を認めた ${ }^{6)}$ 。このことより, 分泌型 CD100 の過剩産生により, 自己抗体の産生が促進 される可能性が示唆された.

\section{CD100 と実験的自己免疫性脳脊䯣炎}

CD100 欠損マウスを KLH (keyhole limpet hemocyanin）などのタンパク抗原をフルインドの完全ア ジュバントとともに免疫すると, 抗原特異的 $\mathrm{T}$ 細 胞の出現が障害される。このことは， $\mathrm{T}$ 細胞に強発 現しているCD100，あるいは樹状細胞自身が産生 分泌する分泌型 CD100 が樹状細胞を活性化し, そ れにより $\mathrm{T}$ 細胞が活性化されるというメカニズム が示唆される，同様の機序で，CD100 欠損マウス では MOG (myelin oligodendrocyte glycoprotein) ペプチドで誘導される，ヒトの多発性硬化症のモデ ルである実験的自己免疫性脳春髄炎 (experimental autoimmune encephalomyelitis；EAE）に対して抵 抗性を示す ${ }^{15)}$. 今後 CD100 を標的とした自己免疫 疾患治療への可能性が示されている.

\section{Sema4A と自己免疫疾患}

\section{Sema4A の発現と機能}

Sema4A は免疫系で生理的に機能していることが 
明らかになった 2 番目のセマフォリン分子である16).

Sema4A は CD100 と同様にセマフォリンファミ リーの中でクラス IV に属する膜型の糖蛋白である.

Sema4A は当初, マウスの胎生期に発現するセマフ オリン分子として同定されたが, 成体においても 脳, 肺, 腎臟, 脾臟や精巣など種々の臟器に広く発 現が認められる。免疫細胞における Sema4A の発 現は, 樹状細胞上に強発現しているほか $\mathrm{T}$ 細胞上 にも後述のように, Th1 細胞に選択的に発現誘導さ れることが明らかとなっている.

\section{Sema4A の活性}

リコンビナント Sema4A タンパク (以下 Sema4A$\mathrm{Fc}$ ) の存在下で $\mathrm{CD} 4$ 陽性 $\mathrm{T}$ 細胞を抗 $\mathrm{CD} 3$ 抗体で 刺激すると, 細胞増殖および $\mathrm{IL}-2$ 産生が抗 CD3 抗体単独刺激に比し増強された。 さらに allogeneic な CD4 陽性 $\mathrm{T}$ 細胞と抗原提示細胞間の混合リンパ 球培養反応 (mixed lymphocyte reaction; MLR) に より誘導される $\mathrm{T}$ 細胞の増殖も, Sema4A-Fc を添 加すると増強した ${ }^{16)}$. また, Sema4A 欠損マウス由 来樹状細胞を用いて allogeneic な CD4 陽性 $\mathrm{T}$ 細胞 とMLR を行うと, Sema4A 欠損樹状細胞では野生 型樹状細胞に比べて $\mathrm{T}$ 細胞の増殖が著しく減弱し た ${ }^{17)}$. 以上より, Sema4A が副刺激分子として T 細胞の活性化を増強することが示唆された。

次にマウス $\mathrm{T}$ 細胞リンパ腫株である $\mathrm{EL}-4$ 細胞 から作成した cDNA ライブラリーを用いた発現ク ローニングによる検討で， TIM（T cell immunoglobulin and mucin domain）ファミリーに属する Tim2 が Sema4A の受容体であることが明らかとなっ た ${ }^{16)}$. TIM ファミリーは, 細胞外領域にイムノグ ロブリン様ドメインおよびムチンドメインを有し,

マウスにおいては Tim1 から Tim8 までが同定され ている，ヒトではマウス $\operatorname{Tim} 1, \operatorname{Tim} 3$ および Tim4 に相同性を有する 3 つ遺伝子が同定されているが, Tim2 に相当する遺伝子は同定されていない，Tim 遺伝子は当初, マウスの気道過敏性を決定する Tapr (T-cell and airway phenotype regulator) 遺伝 子座に存在する遺伝子として同定された，Tim-1 には遺伝子多型が認められ，ヒトおよびマウスにお ける気管支喘息，アトピー性皮膚炎といった Th2 反応に依存する疾患の発症に寄与していることが示 されている18). また Tim3 は Th1 細胞上に発現し, Th1 反応およびマクロファージの活性化に関与する ことが報告されており ${ }^{19)}$ ，TIM ファミリーが Th1/
Th2 反応の制御に関与することが示唆されている20).

\section{Sema4A ¿ EAE}

Sema4A は休止期の $\mathrm{T}$ 細胞には殆ど発現が認め られないが, näive CD4 陽性 T 細胞を IL-12 と抗 IL-4 抗体で誘導した Th1 細胞上に Sema4A が特異 的に誘導される. Sema4A 欠損マウス由来の $\mathrm{T}$ 細 胞では, in vitro および in vivo ともに Th1 細胞へ の分化が顕著に障害されており ${ }^{17)}$, Sema4A は Th1 /Th2 分化の制御に重要な役割を担っていることが 示されている.

Sema4A-Fc 投与下, タンパク抗原とフルイント の完全アジュバントとともに免疫すると, 非投与マ ウスに比べ抗原特異的な $\mathrm{T}$ 細胞の増加を認める.

逆に, Sema4A 欠損マウスでは, 抗原特異的 $\mathrm{T}$ 細 胞の出現が障害される.このことより, Sema4Aの $\mathrm{T}$ 細胞-樹状細胞間相互作用への関与が示されてい る。また，ヒトの多発性硬化症のモデルである EAE モデルマウスに抗 Sema4A 抗体を投与すると EAEの発症が抑制されたことより ${ }^{16)}$, Sema4Aを 標的とした自己免疫疾患治療への可能性も示されて いる.

\section{III. クラス III セマフォリンと自己免疫疾患}

Mangasser のグループは, 関節リウマチの病因関 連遺伝子を探索する過程でサブトラクション法を行 い, 関節リウマチの滑膜培養細胞で健常人に比し優 位に発現が上昇している遺伝子として, クラス III セマフォリンである Sema3C を報告している21). 一方, Miller らは, 関節リウマチ患者の滑膜に浸潤 しているマクロファージや線維芽細胞上に Sema3C の発現が認められ, 滑膜における Sema3C 発現細 胞数と副交感神経の分布に負の相関があると報告し ている22).

\section{おわりに}

以上述べてきたように, 免疫系におけるセマフォ リンの機能は, $\mathrm{B}$ 細胞のホメオスターシス維持, 副 刺激分子としての機能, $\mathrm{T}$ 細胞の $\mathrm{Th} 1 / \mathrm{Th} 2$ 分化制 御と, その機能は非常にバラエティー富んでいる. 最近, 筆者らは上述したセマフォリン分子のほかに も免疫細胞に発現する新たなセマフォリン分子を見 出すとともに，これらの免疫制御への関与を示唆す る知見を得つつある. 今後の解析により, セマフォ リン分子による免疫制御機構が明らかにされるだけ 
でなく，セマフォリン分子群を標的とした自己免疫 疾患やアレルギー疾患および感染症治療に向けた, 新たなアプローチが期待される.

\section{文献}

1) Luo, Y. et al. : A protein in brain that induces the collapse and paralysis of neuronal growth cones. Cell, 75 : 217-227,1993.

2) Kolodkin, A. L. et al. : The semaphoring genes encode a family of transmembrane and secreted growth cone guidance molecules. Cell, 75 : 1389-1399, 1993.

3) Semaphorin Nomenclature Committee : Unified nomenclature for the semaphorins/collapsins. Cell, 97 : 551-552, 1999.

4) Kikutani, H. and Kumanogoh, A. : Semaphorins in interactions between $\mathrm{T}$ cells and antigen presenting cells. Nat Rev Immunol, 3 : 159-167, 2003.

5) Bougeret, $C$. et al. : Increased surface expression of a newly identified $150-\mathrm{kDa}$ dimer early after human $\mathrm{T}$ lymphocyte activation. $J$ Immunol, 148 : 318-323, 1992.

6) Wang, X. et al. : Functional soluble CD100/ Sema4D released from activated lymphocytes : possible role in normal and pathologic immune responses. Blood, 97 : 3498-3504, 2001.

7) Kumanogoh, A. et al. : Identification of CD72 as a lymphocyte receptor for the class IV semaphorin CD100:a novel mechanism for regulating B cell signaling. Immunity, 13 : 621631,2000 .

8) Shi, W. et al. : The class IV semaphorin CD100 plays nonredundant roles in the immune system : defective $B$ and $T$ cell activation in CD100-deficient mice. Immunity, 13 : 633-642, 2000.

9) Watanabe, C. et al.: Enhanced immune responses in transgenic mice expressing a truncated form of the lymphocyte semaphorin CD100. J. Immunol., 167 : 4321-4328, 2001.

10) Tamagunone, L. et al. : lexins are a large family of receptors for transmembrane, secreted, and GPI-anchored semaphorins in vertebrates. Cell, 99 : 71-80, 1999.

11) Adachi, T. et al. : The B cell surface protein CD72 recruits the tyrosine phosphatase SHP-1 upon tyrosine phosphorylation. J. Immunol., 160 : 4662-4665, 1998.

12) Pan, C. et al. : CD72-defeicient mice reveal nonredundant roles of CD72 in B-cell development and activation. Immunity, 11 : 495, 1999.

13) Granziero, L. et al. : CD100/PlexinB1 interactions sustain proliferation and survival of normal and leukemic $\mathrm{CD}^{+}$B lymphocytes. Blood, $101:$ 1962-1969, 2003.

14) Kumanogoh, A. et al. : Requirement for CD100-CD72 interactions in fine-tuning of Bcell antigen receptor signaling and homeostatic maintenance of the B-cell compartment. Int. Immunol., 2005, in press.

15) Kumanogoh, A. et al.: Requirement for the lymphocyte semaphoring, CD100, in the induction of antigen-specific $T$ cells and the maturation of dendritic cells. J. Immunol., 169 : 11751181, 2002.

16) Kumanogoh, A. et al. : Class IV semaphoring Sema4a enhances T-cell activation and interacts with Tim-2. Nature, 419 : 629-633, 2002.

17) Kumanogoh, A. et al. : Nonredundant roles of Sema4A in the immune system : defective $T$ cell priming and Th1/Th2 regulation in Sema4Adeficient mice. Immunity, $22:$ 1-12, 2005.

18) McIntire, J. J. et al. : Identification of Tapr (an airway hyperreactivity regulatory locus) and the linked Tim gene family. Nature Immunol, 2: 1109-1116, 2001.

19) Monney, L. et al. : TH1-specific cell surface protein Tim-3 regulates macrophage activation and severity of an autoimmune disease. Nature, 415 : 536-541, 2002.

20) Kuchroo, V. K. et al. : The TIM gene family : emerging roles in immunity and disease. Nat Rev Immunol. 3 : 454-462, 2003.

21) Mangasser, S. K. et al. : Identification of human semaphorin E gene expression in rheumatoid synovial cells by mRNA differential display. Biochem. Biophys. Res. Commun., 234 : 153-156, 1997.

22) Miller, L. E. et al. : Increased Prevalence of Semaphorin 3C, a Repellent of sympathetic Nerve Fibers, in the Synovial Tissue of Patients With Rheumatoid Arthritis. Arthritis Rheum., 50 : 1156-1163, 2004. 